\title{
Welcome from the OLBI Director
}

As the new Director of the Official Languages and Bilingualism Institute, it is a pleasure to welcome readers to the eighth issue of the Cahiers de l'ILOB/OLBI Working Papers. This issue showcases contributions stemming from the continued work of the OLBI research centre, the Canadian Centre for Studies and Research on Bilingualism and Language Planning (CCERBAL). The volume specifically addresses themes explored during the 2016 CCERBAL Conference: Bilingual from birth: Process, pedagogy and policy. We are proud of the diversity of scholarship represented. The articles highlight the importance and richness of the varied aspects linked to the topic of bilingualism and make valuable interdisciplinary connections, in particular with the fields of both developmental and social psychology, in addition to the more traditional areas of language pedagogy, assessment, and policy. I wish you all happy reading and hope you will find this edition compelling and useful for your scholarship.

Jérémie Séror

Director and Associate Dean

Official Languages and Bilingualism Institute

Ottawa, July 2017 